This document was prepared in conjunction with work accomplished under Contract No. DE-AC09-96SR18500 with the U.S. Department of Energy.

This work was prepared under an agreement with and funded by the U.S. Government. Neither the U. S. Government or its employees, nor any of its contractors, subcontractors or their employees, makes any express or implied: 1 . warranty or assumes any legal liability for the accuracy, completeness, or for the use or results of such use of any information, product, or process disclosed; or 2 . representation that such use or results of such use would not infringe privately owned rights; or 3 . endorsement or recommendation of any specifically identified commercial product, process, or service. Any views and opinions of authors expressed in this work do not necessarily state or reflect those of the United States Government, or its contractors, or subcontractors. 
IMECE2008-67572

\title{
GAS MIXING ANALYSIS IN A LARGE-SCALED SALTSTONE FACILITY
}

\author{
Si Y. Lee \\ Savannah River National Laboratory \\ Savannah River Site \\ Aiken, SC 29808 \\ Phone: (803) 725-8462; (803) 725-8203 \\ si.lee@srnl.doe.gov
}

\begin{abstract}
Computational fluid dynamics (CFD) methods have been used to estimate the flow patterns mainly driven by temperature gradients inside vapor space in a large-scaled Saltstone vault facility at Savannah River site (SRS). The purpose of this work is to examine the gas motions inside the vapor space under the current vault configurations by taking a three-dimensional transient momentum-energy coupled approach for the vapor space domain of the vault. The modeling calculations were based on prototypic vault geometry and expected normal operating conditions as defined by Waste Solidification Engineering. The modeling analysis was focused on the air flow patterns near the ventilated corner zones of the vapor space inside the Saltstone vault.
\end{abstract}

The turbulence behavior and natural convection mechanism used in the present model were benchmarked against the literature information and theoretical results. The verified model was applied to the Saltstone vault geometry for the transient assessment of the air flow patterns inside the vapor space of the vault region using the potential operating conditions.

The baseline model considered two cases for the estimations of the flow patterns within the vapor space. One is the reference nominal case. The other is for the negative temperature gradient between the roof inner and top grout surface temperatures intended for the potential bounding condition. The flow patterns of the vapor space calculated by the CFD model demonstrate that the ambient air comes into the vapor space of the vault through the lower-end ventilation hole, and it gets heated up by the Benard-cell type circulation before leaving the vault via the higher-end ventilation hole. The calculated results are consistent with the literature information. Detailed results and the cases considered in the calculations will be discussed here.
Keywords: Flow Patterns, Computational Fluid Dynamics, Heat Transfer, Saltstone Vault Facility

\section{INTRODUCTION}

Waste Solidification Engineering at Savannah River Site (SRS) has been evaluating the potential flammable conditions in the vapor space of Saltstone vault facility for the safety analysis. In order to help assess the potential for benzene layer formation on top of the grout, Savannah River National Laboratory (SRNL) was requested to develop a computational model of the Vault vapor space to estimate the nature of air movement inside the vault. The vault geometrical configurations are shown in Fig. 1.

The vault has two breathing holes, which are located along the diagonally opposed location as shown in Fig. 1. The main objective of this work is to examine the gas motions inside the vapor space under the current vault configurations by taking a computational fluid dynamics (CFD) modeling approach [1]. The modeling domain of the present analysis is shown in Fig. 1. The modeling analysis was focused on the impacts of two breathing holes on the gas flow patterns due to the mass and energy exchanges between the cooler gas of the ambient air and the warmer vapor space gas of the vault, especially, under hot summer conditions.

In this work two modeling cases were considered. One case represents the nominal reference conditions for the baseline analysis. The other is for the case with negative temperature gradient, that is, Saltstone vault has the inner roof surface temperature $5^{\circ} \mathrm{C}$ higher than the bottom surface of Fig. 1 . The latter case corresponds to the potential bounding case in terms of flammable gas mixing, which is expected under the hot summer conditions. 


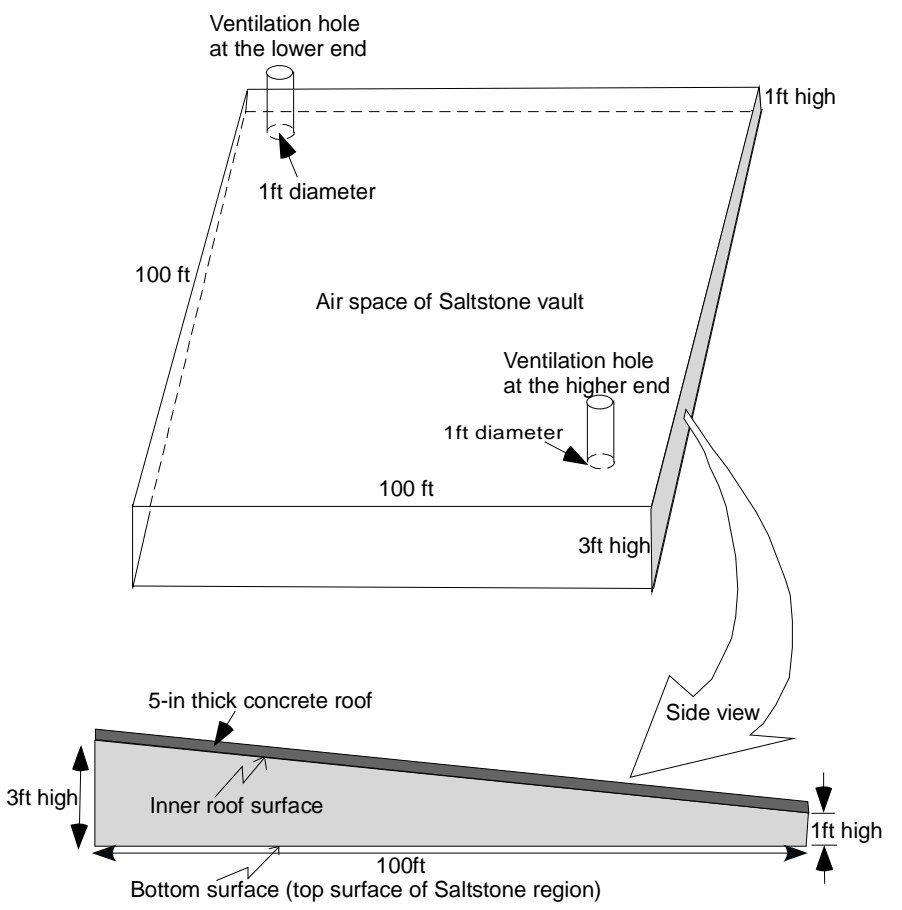

Figure 1. Modeling domain of vapor space for Saltstone Vault facility used for the present work.

A series of sensitivity calculations for different vapor space height and grout surface temperatures is also considered. The primary objective of this work is to examine the impacts of the gas flow patterns due to the changes of the vapor space height and grout surface temperature. The modeling results will assist in understanding the qualitative gas flow patterns within the vapor space of the Saltstone vault and ambient air circulation paths through the two ventilation holes under the potential operating scenarios. This paper will discuss the modeling and analysis results.

\section{NOMENCLATURE}

$\begin{array}{ll}\text { A } & \text { Area }\left(\mathrm{m}^{2}\right) \\ { }^{\circ} \mathrm{C} & \text { Degree Centigrade (or Celsius) } \\ \mathrm{CFD} & \text { Computational Fluid Dynamics } \\ \mathrm{d} & \text { Diameter }(\mathrm{m}) \\ \mathrm{h} & \text { Air inlet height }(\mathrm{m}) \\ \mathrm{H} & \text { Room height }(\mathrm{m}) \\ \mathrm{hr} & \text { Hour } \\ \mathrm{kg} & \text { Kilogram } \\ \mathrm{L} & \text { Length }(\mathrm{m}) \\ \mathrm{m} & \text { Meter } \\ \mathrm{min} & \text { Minute } \\ \mathrm{Pa} & \text { Pascal }\left(\mathrm{N} / \mathrm{m}^{2}\right) \\ \mathrm{Re} & \text { Reynolds number }(\mathrm{d} \rho \mathrm{Lu} / \mu) \\ \mathrm{s} \text { or sec } & \text { Second }\end{array}$

SRNL Savannah River National Laboratory

$\begin{array}{ll}\begin{array}{l}\text { SRS } \\ \mathrm{t}\end{array} & \begin{array}{l}\text { Savannah River Site } \\ \text { thickness (m) or time (second) }\end{array} \\ \mathrm{u} & \text { Local air velocity }(\mathrm{m} / \mathrm{sec}) \\ \mathrm{U}_{\mathrm{o}} & \text { Inlet velocity }(\mathrm{m} / \mathrm{sec}) \\ \mathrm{W} & \text { Room width }(\mathrm{m}) \\ \mathrm{x}, \mathrm{y}, \mathrm{z} & \begin{array}{l}\text { Three coordinate system for the computational } \\ \text { domain as shown Fig. } 2\end{array} \\ \rho & \text { Density }\left(\mathrm{kg} / \mathrm{m}^{3}\right) \\ \kappa & \text { Turbulence kinetic energy }\left(\mathrm{m}^{2} / \mathrm{sec}^{2}\right) \\ \varepsilon & \text { Turbulence dissipation rate }\left(\mathrm{m}^{2} / \mathrm{sec}^{3}\right) \\ \mu_{\mathrm{t}} & \text { Dynamic viscosity }(\mathrm{kg} / \mathrm{m}-\mathrm{sec})\end{array}$

\section{MODELING APPROACH AND SOLUTION METHOD}

A three-dimensional CFD approach was taken to calculate flow patterns for the gas flow patterns of Salstone vault and to examine the qualitative air circulation paths between the ambient air and vapor space gas through two breathing holes located at the roof of the vault. The detailed dimensions and geometrical information as modeled are presented in Fig. 1. A finite volume CFD code, FLUENT ${ }^{\mathrm{TM}}$, was used here in creating the modeling geometry and in solving the governing equations for the present work. A computational domain of the prototypic vault geometry was non-uniformly discretized by a non-orthogonal and hexahedral mesh for the numerical simulations. Final nodes of about 150,000 meshes were established from a mesh sensitivity analysis. The modeling calculations were performed using the following assumptions:

- Typical gas flow behaviors of the vapor space in Saltstone vault due to the temperature difference between the inner roof and top grout surface are similar to the one driven by the air movement.

- Air was assumed to follow ideal gas behavior.

- Top grout surface corresponding to bottom surface in Fig. 1 is assumed to be flat.

- Ambient air temperature is assumed to be constant, and it is $41^{\circ} \mathrm{C}$.

- The initial conditions for the vapor space are stagnant and the same as ambient temperature $41^{\circ} \mathrm{C}$.

The flow conditions for the vault operations are assumed to be fully turbulent since Reynolds numbers for typical operating conditions are in the range of 24,000 based on the inlet conditions of the ventilation hole. A standard two-equation turbulence model, the $\kappa-\varepsilon$ model [2], was used since previous work [3] showed that the two-equation model predicts the flow evolution of turbulent flow in a large stagnant fluid domain with reasonable accuracy. This model specifies the turbulent or "eddy" viscosity $\mu_{t}$ by the empirical equation.

$\mu_{t}=\left(\frac{C_{\mu} \rho_{f} k^{2}}{\varepsilon}\right)$ 
In eq. (1) $C_{\mu}$ is an empirical constant. In the present calculations, $C_{\mu}$ is 0.09 [2]. Thus, the turbulent viscosity is computed by solving two transport equations for $k$ (turbulent kinetic energy) and $\varepsilon$ (rate of dissipation of turbulent energy). The governing equations to be solved for the present work are composed of one continuity equation, three momentum equations for the three component directions ( $x, y$, and $z$ directions), one energy equation, and two constitutive equations for the turbulence descriptions. The detailed descriptions for the governing equations and computational methods are provided in the previous work [1]. The model is a full threedimensional representation of the entire gas space to capture significant phenomena related to the turbulent behavior of gas flow evolution

Air was used to simulate the gas in the vapor space within the vault, assuming that it would give an acceptable representation of the flow patterns. Governing equations for the entire computational domain were solved with FLUENT ${ }^{\mathrm{TM}}$ for two different cases in transient simulation mode. They are the baseline reference and the bounding cases as described in the previous section. The modeling conditions for the nominal baseline case are summarized in Table 1 . As shown in the table, boundary conditions for two ventilation holes of the vault system were set as $250 \mathrm{~Pa}$ gauge pressure since the amplitude of the sinusoidal pressure oscillations due to diurnal temperature variations is set at 2.5 mbar about the mean pressure of 1,103 mbar [4].

The key areas in the present analysis such as the turbulence and natural convection behaviors were benchmarked against the literature and theoretical results $[1,3]$ in order to demonstrate the adequacy of the software for the vault model since the modeling results are to support a safety significant calculation.

Finally, the benchmarked modeling equations were applied to the Saltstone vault model using the computational domain as shown in Fig. 1. Design and modeling conditions for the baseline calculation are presented in Table 1.
Table 1. Reference modeling conditions used for the baseline calculations in the present modeling analysis.

\begin{tabular}{|c|c|}
\hline Parameters & Baseline conditions \\
\hline $\begin{array}{c}\text { Modeling domain size } \\
\text { (see Fig. 1) }\end{array}$ & $\begin{array}{c}\text { 100ft x 100ft x 1 ft (lower end) } \\
\text { X } 3 \mathrm{ft} \text { (higher end) }\end{array}$ \\
\hline Roof thickness & 5 inches \\
\hline Ambient temperature & $105 \mathrm{~F}\left(41^{\circ} \mathrm{C}\right)$ \\
\hline Initial gas temperature for vapor space & $105 \mathrm{~F}\left(41^{\circ} \mathrm{C}\right)$ \\
\hline Bottom surface of domain (see Fig. 1$)$ & $158 \mathrm{~F}\left(70^{\circ} \mathrm{C}\right)$ \\
\hline Solar heat flux & $400 \mathrm{~W} / \mathrm{m}^{2}$ \\
\hline Ventilation hole & $1 \mathrm{ft}$ \\
\hline Ventilation hole diameter & $4 \mathrm{ft}$ \\
\hline Chimney height of ventilation hole & Natural convection \\
\hline Primary cooling mechanism & \\
\hline
\end{tabular}

\section{RESULTS AND DISCUSSIONS}

The present model employed two-equation turbulence described in terms of turbulent dissipation and eddy diffusivity, and ideal gas law was used in association with natural convection mechanism for the entire computational domain as shown in Fig 1.

The flow conditions for the Saltstone vault facility are assumed to be fully turbulent since Reynolds numbers for typical operating conditions are in the range of $2 \times 10^{4}$. A standard two-equation turbulence model, referred to as $k-\varepsilon$ model [2], was used since benchmarking results against the literature data [5] showed that the model predicts turbulent flow evolution in a large fluid domain with reasonable accuracy. Fig. 2 compares the model predictions for the standard twoequation model with the test results available in the literature.

The benchmarked model was applied to the Saltstone vault geometry for the transient assessment of the gas flow patterns inside the vapor space of the vault region using the potential boundary conditions. 

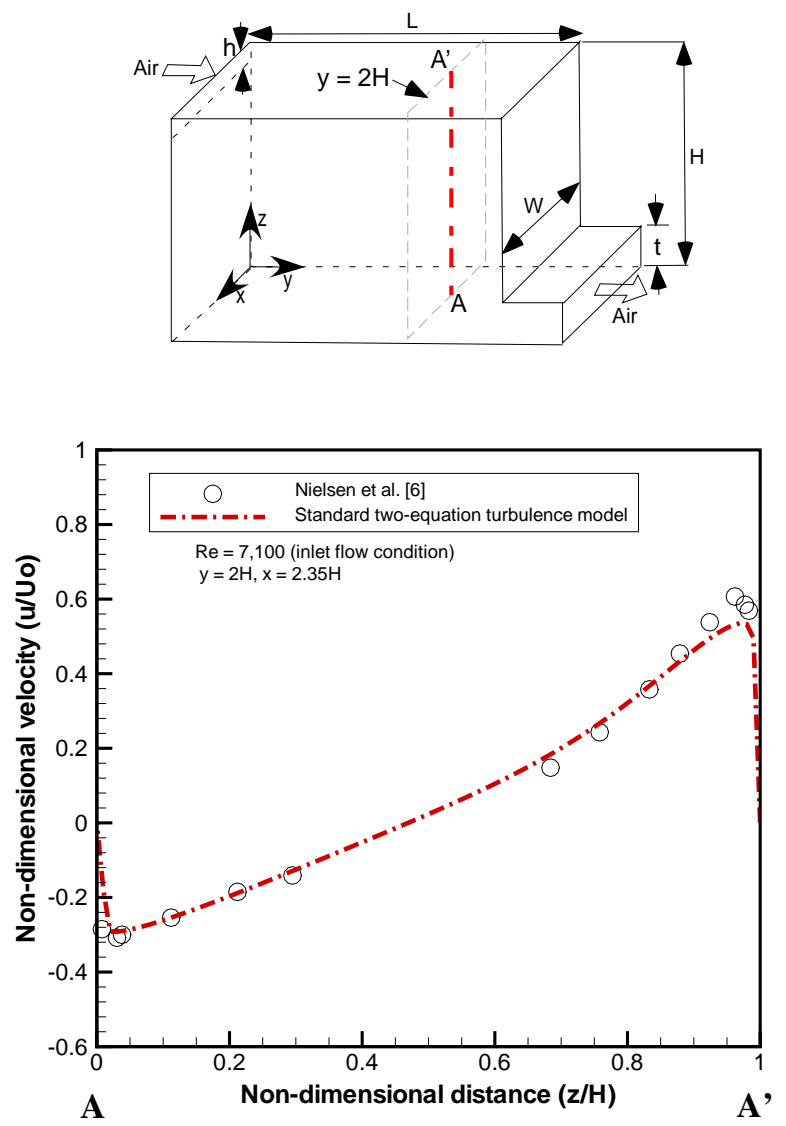

$(\mathrm{L} / \mathrm{H}=3.1, \mathrm{~W} / \mathrm{H}=4.7, \mathrm{~h} / \mathrm{H}=0.056, \mathrm{t} / \mathrm{H}=0.16, \mathrm{H}=0.0893 \mathrm{~m})$

Fig. 2. Benchmarking results of non-dimensional horizontal air velocity along the line $A-A^{\prime}$ on the plane of $y=2 \mathrm{H}$ distance from the air inlet plane at $\operatorname{Re}=7,100$ inlet flow (inlet air velocity, $\mathrm{U}=10.371 \mathrm{~m} / \mathrm{sec}$ )

The present work considered two cases for the estimations of the flow patterns within the vapor space. One is the baseline reference case as provided in Table 1 . The other is for the negative temperature gradient between the roof inner and top grout surface temperatures intended for the potential bounding condition. For this case, wall temperature of the inner roof is assumed to be $5^{\circ} \mathrm{C}$ higher than that of the bottom surface for the vault air region shown in Fig. 1. Pressures at both holes are assumed to be maintained as $250 \mathrm{~Pa}$ gauge pressure given by the literature data [4]. As the initial conditions for the present transient simulations, the vapor space is assumed to be stagnant at ambient temperature $41^{\circ} \mathrm{C}$.

At 7 hours transient time since the beginning of the initial conditions, the temperature contours for the plane crossing the lower inlet hole is shown in Fig. 3. It is clearly shown that the ambient cooler air comes into the vapor space domain through the ventilation hole of the lower end, and then it hits the top surface of the grout region. Figure 4 presents the temperature distributions for the plane crossing the ventilation holes near the corner of the higher end. The transient results show that maximum temperature of the roof inner wall is still about $10^{\circ} \mathrm{C}$ lower than the top grout surface temperature, which is provided as $70^{\circ} \mathrm{C}$ boundary condition shown in Table 1 . This case corresponds to positive temperature gradient between the roof inner and top grout surface temperatures. In this case, the velocity flow patterns corresponding to the temperature distributions are shown in Figs. 5 and 6. The flow pattern results confirmed the air circulations through the two holes. It is noted that the ambient air of about $41^{\circ} \mathrm{C}$ comes into the gas space through the lower end hole, and after it is heated up to $64^{\circ} \mathrm{C}$ at 7 hours transient time, it comes out of the vault via the higher end one.

Density distributions along the diagonal plane crossing the two ventilation holes confirm that heavier air comes into the hole located near the corner of the lower end region. Temperature distributions at the entire plane crossing the middle elevation of the vapor space are shown in Fig. 7. Density distribution patterns are very similar to the temperature distributions, showing the local cell patterns. These results are consistent with the literature information $[6,8]$. Velocity flow patterns at the mid-plane of the vapor space inside the vault are also shown in Fig. 8. It is noted that the flow patterns consists of small cells like honey comb as the ambient cooler air gets heated up during the residence time inside the vault. Maximum speed of air movement is at the two ventilation holes of the vault, and it reaches about $1.2 \mathrm{~m} / \mathrm{sec}(\sim 4 \mathrm{ft} / \mathrm{sec})$. Detailed results are shown in Fig. 9. Positive velocity in the figure indicates the gas flow leaving the vapor space through the ventilation hole.

As the second case, the potential negative temperature gradient is considered as the bounding case. This case corresponds to the case that the inner roof surface temperature is higher than the top grout surface temperature. The negative temperature gradient case has $5^{\circ} \mathrm{C}$ difference between the top and bottom surfaces of the domain as shown in Fig. 1. The results show that the vapor space near the lower end region gets heated more quickly than the higher end region since the heat transfer mechanism at early transient period is controlled primarily by the conduction mode. During the first 90 -second transient period, it is shown that the gas contained inside the vapor space of the vault is breathing out through both of the two holes because of the dominant gas buoyancy. When the transient time reaches about 3 minutes, the ambient air starts to flow into the vapor space of the vault via the lower-end hole and to flow out through the higher-end hole. As shown in Fig. 10, the air circulation patterns are formed through both ventilation holes. It is noted that flow patterns for this case are very similar to those of the first case, the positive temperature gradient. The results for both cases confirm the consistent circulation patterns in terms of gas energy exchanges via both breathing holes as shown in Fig. 11. 
The conclusive flow patterns of the vapor space obtained by the CFD modeling results are summarized in Fig. 11 in a qualitative way, which is consistent with the literature information [8]. Table 5 summarizes the quantitative results for the air flow rate coming into the vapor space through the ventilation hole near the lower end of the vault under the two modeling conditions considered in the present work.

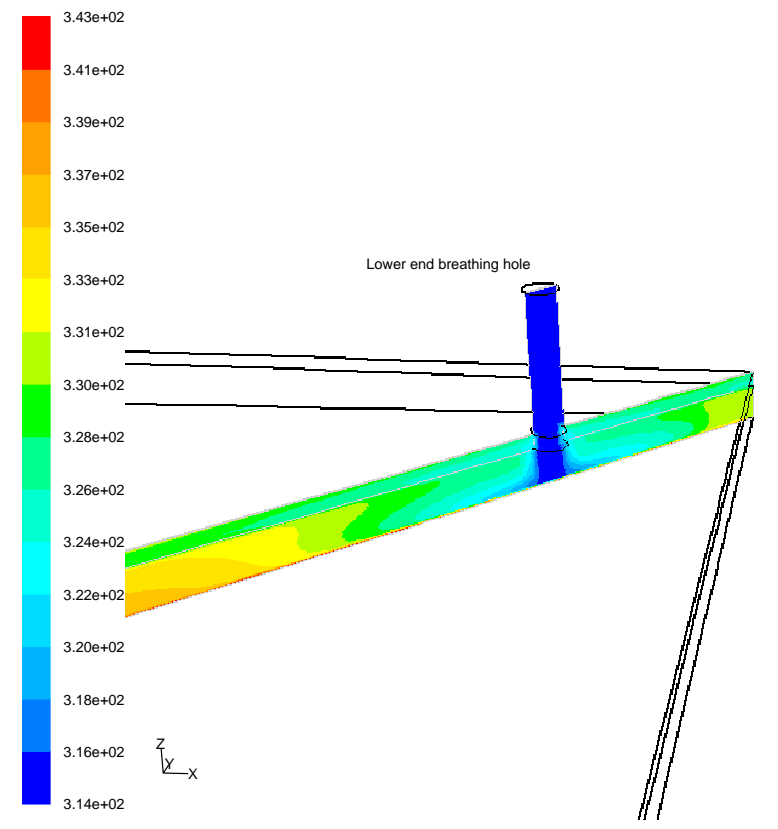

Figure 3. Temperature contours near the lower end breathing hole at $\mathrm{t}=7$ hours (Red and blue regions are $70^{\circ} \mathrm{C}$ and $41^{\circ} \mathrm{C}$, respectively)

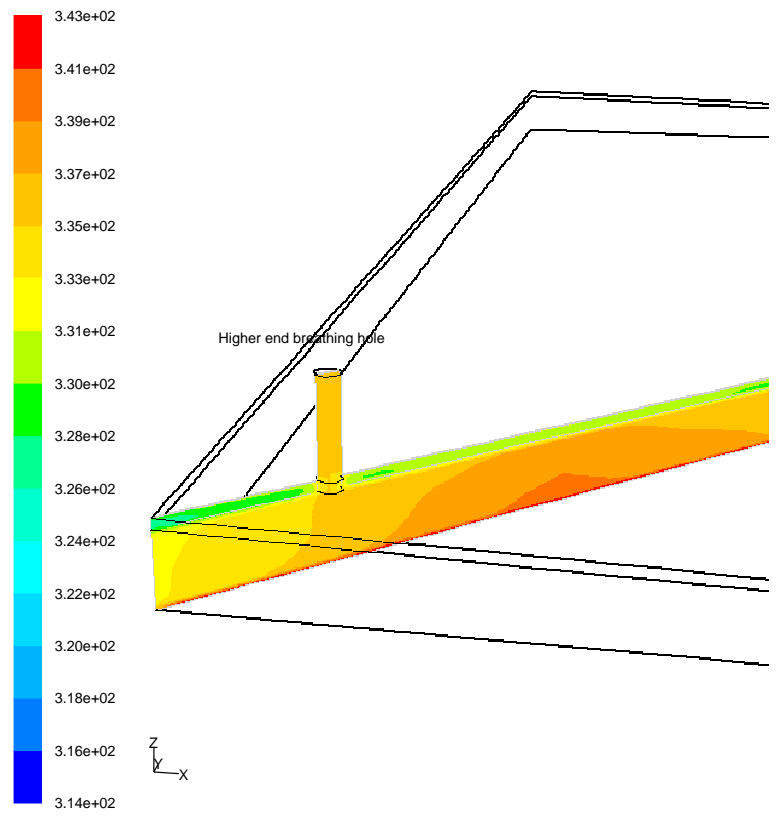

Figure 4. Temperature contours near the higher end breathing hole at $\mathrm{t}=7$ hours (Red and blue regions are $70^{\circ} \mathrm{C}$ and $41^{\circ} \mathrm{C}$, respectively)

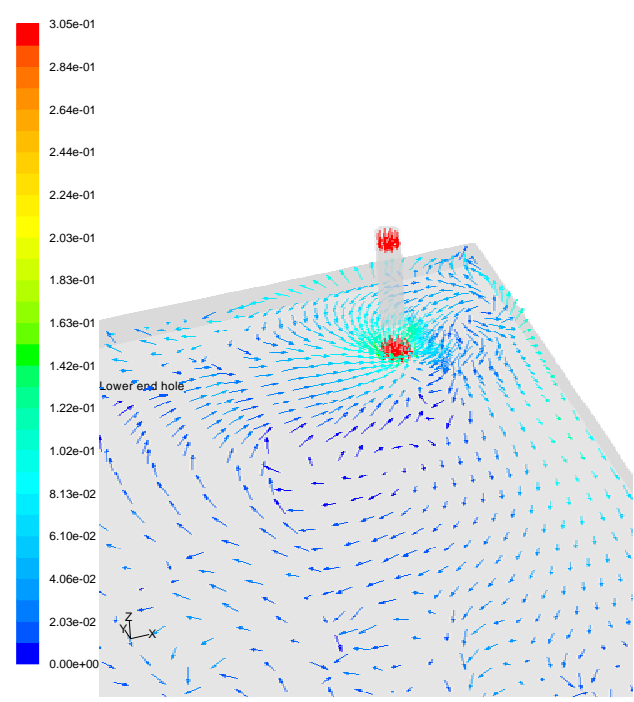

Figure 5. Air flow patterns near lower end at $\mathrm{t}=7$ hours 


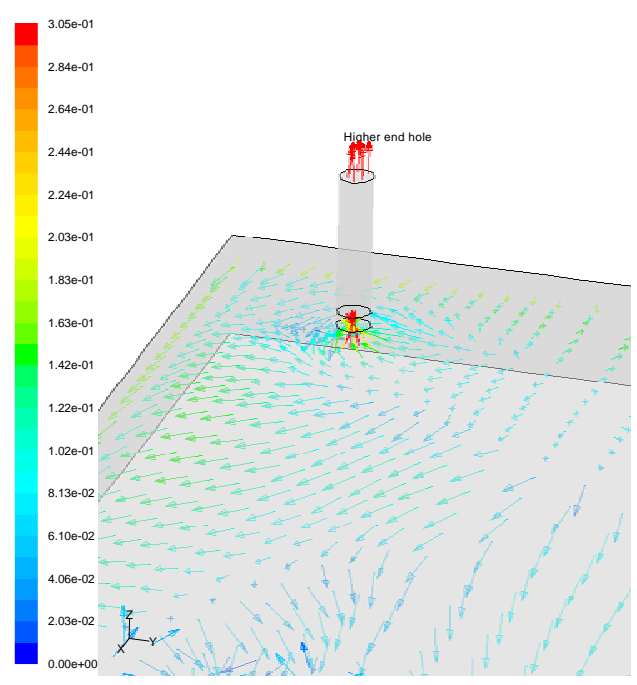

Figure 6. Air flow patterns near higher end at $\mathrm{t}=7$ hours

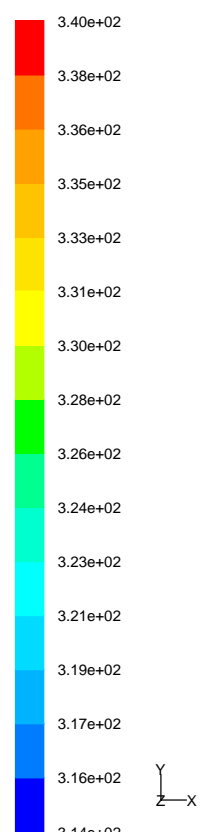

Figure 7. Temperature distributions at the mid-plane of the gas space showing the honeycomb-type heat transfer at $\mathrm{t}=7$ hours (Red and blue regions are $67^{\circ} \mathrm{C}$ and $41^{\circ} \mathrm{C}$ , respectively)

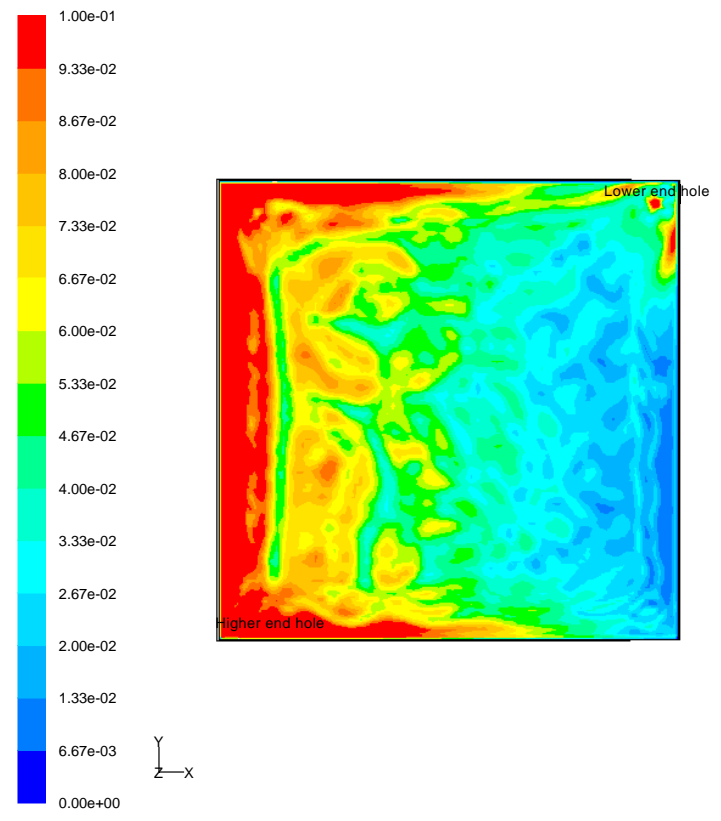

Figure 8. Velocity flow patterns at the mid-plane of the vapor space inside the vault at $\mathrm{t}=7$ hours, indicating that red region has local velocity higher than $0.1 \mathrm{~m} / \mathrm{sec}$.
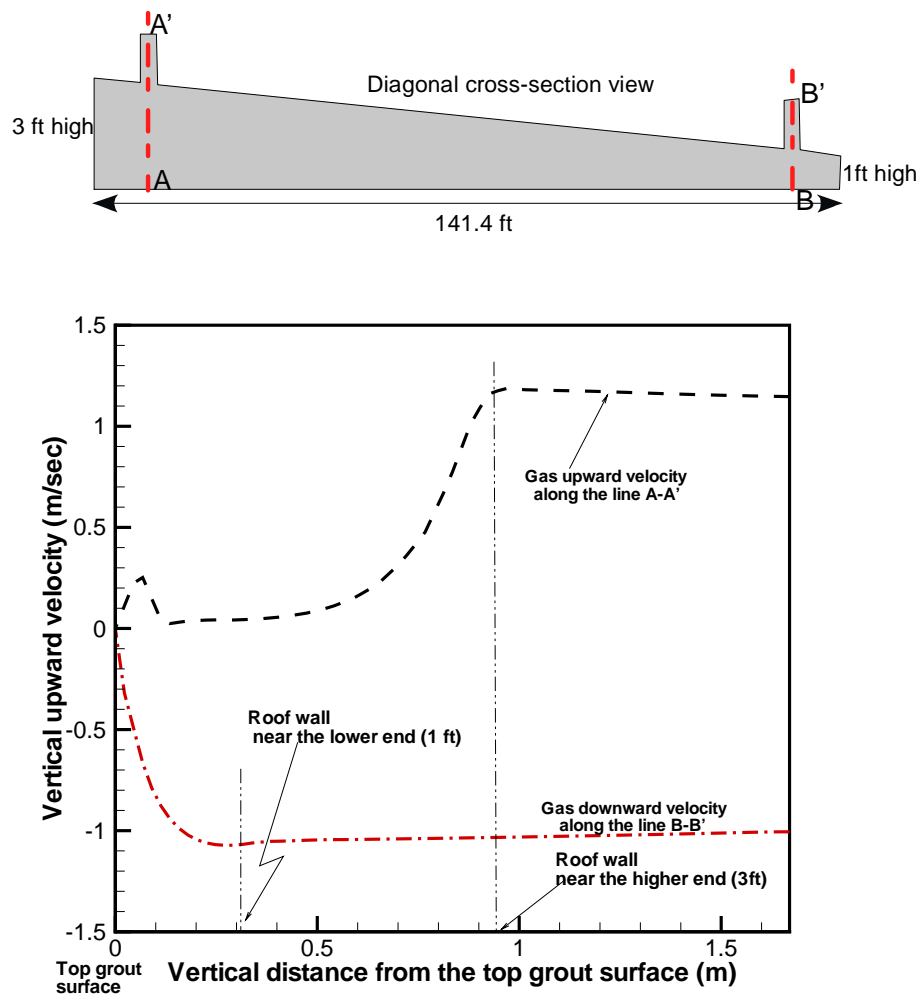

Figure 9. Gas upward velocity profile along the vertical lines A-A' and B-B' of the two ventilation holes indicating that the lower end hole has downward airflow patterns under the baseline case 

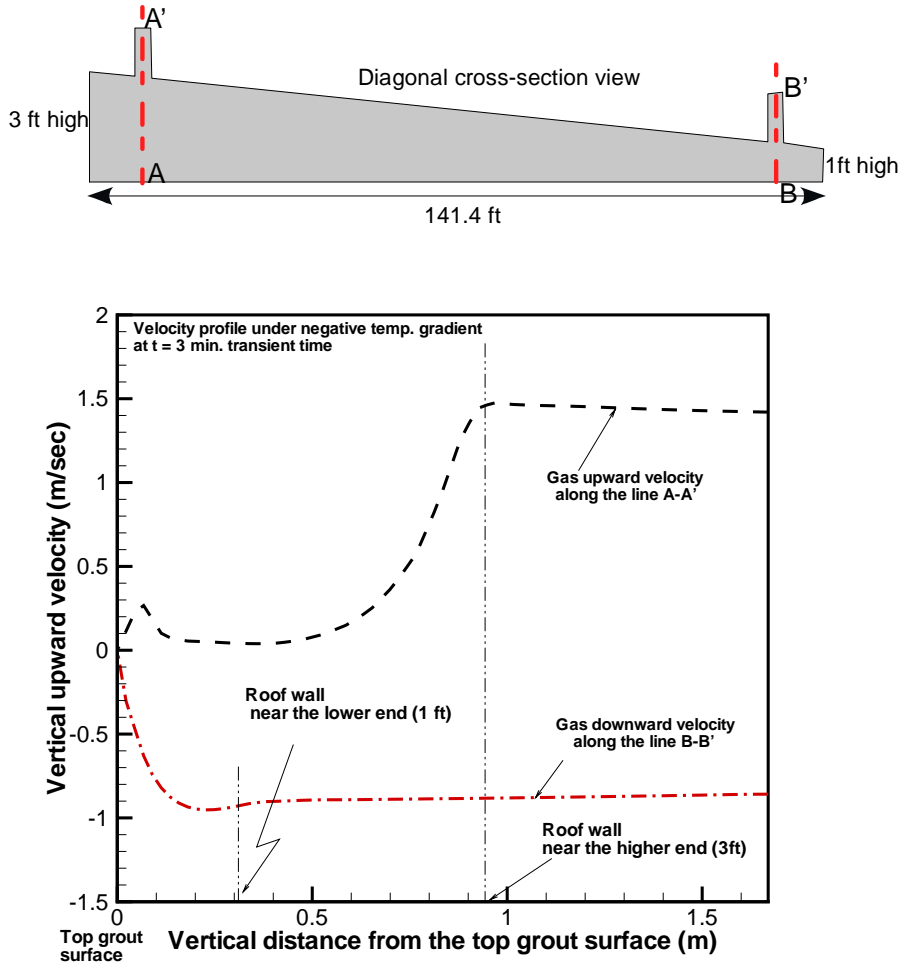

Figure 10. Gas upward velocity profile along the vertical lines A-A' and B-B' of the two ventilation holes under the negative temperature gradient between the inner roof and top grout surface at 3-min. transient time, noting that the lower end hole has the gas flow patterns switched from the upward flow of the 90-second transient to the downward one of the later transient

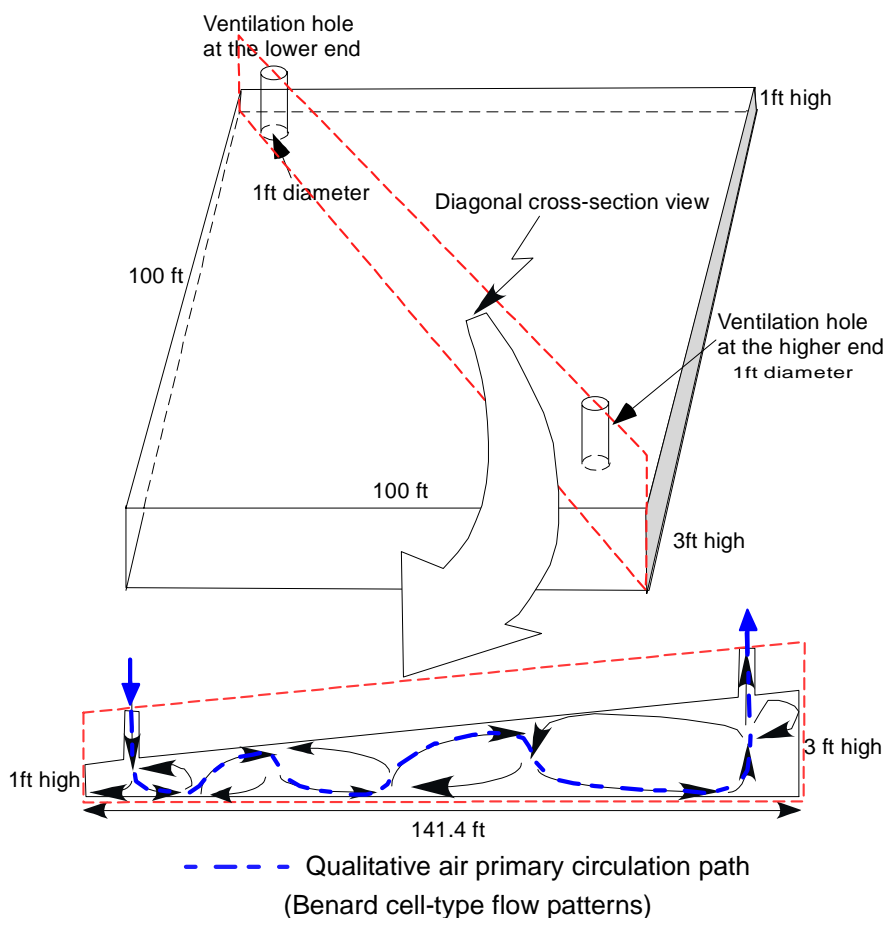

Figure 11. Qualitative gas circulation patterns obtained by the present CFD modeling calculations for the vapor space of Saltstone vault, showing that the ambient air comes into the vapor space of the vault through the ventilation hole located near the lower end

Table 2. Quantitative results for the established air flow rate coming into the vapor space through the ventilation hole near the lower end of the vault under the two modeling conditions considered in the present work

\begin{tabular}{|c|c|c|}
\hline Cases & $\begin{array}{c}\text { Average air velocity } \\
\text { coming into the } \\
\text { vapor space within } \\
\text { the vault }\end{array}$ & $\begin{array}{c}\text { Air flowrate coming } \\
\text { into the vapor space via } \\
\text { the lower inlet hole } \\
\text { (1-ft diameter) }\end{array}$ \\
\hline $\begin{array}{c}\text { Positive } \\
\text { temperature } \\
\text { gradient* }\end{array}$ & $0.66(\mathrm{~m} / \mathrm{sec})+$ & $760 \mathrm{gpm}$ \\
\hline $\begin{array}{c}\text { Negative } \\
\text { temperature } \\
\text { gradient** }\end{array}$ & $0.56(\mathrm{~m} / \mathrm{sec})+$ & $648 \mathrm{gpm}$ \\
\hline
\end{tabular}

Note:* Baseline modeling conditions as provided by Table 1

** Modeling conditions for $75^{\circ} \mathrm{C}$ roof inner temperature and $70^{\circ} \mathrm{C}$ bottom surface temperature under the same modeling domain as the baseline case

+ Average flow velocity $\left(V_{\text {avg }}\right)$ was computed by averaging local velocity $v$ over the ventilation hole area

$\left(A_{\text {hole }}\right): V_{\text {avg }}=\frac{1}{A_{\text {hole }}} \int_{A_{\text {hole }}} v d A$ 


\section{CONCLUSION}

A computational fluid dynamics (CFD) method was applied to estimate the flow patterns for vapor space domain inside the Saltstone vault. The CFD model took a three-dimensional transient momentum-energy coupled approach. The flow conditions for the vault operations are assumed to be fully turbulent since Reynolds numbers for typical operating conditions are in the range of 24,000 based on the inlet conditions of the ventilation hole. A standard two-equation turbulence model was used for this work.

The air turbulence behavior used in the present model was benchmarked against the literature information. The verified model was applied to the Saltstone vault geometry for the transient assessment of the gas flow patterns inside the vapor space of the vault region using the boundary conditions as provided by the potential operating conditions.

The present model considered two cases for the estimations of the flow patterns within the vapor space. One is the reference baseline case. The other is for the negative temperature gradient between the roof inner and top grout surface temperatures intended for the potential bounding condition. The flow patterns of the vapor space calculated by the CFD model demonstrate that the ambient air comes into the vapor space of the vault through the lower-end ventilation hole, and it gets heated up by the Benard-cell type circulation before leaving the vault via the higher-end hole. The calculated results are consistent with the literature information.

\section{ACKNOWLEDGMENT}

This work was funded by U.S. Department of Energy and performed at the Savannah River National Laboratory, which is operated by the Washington Savannah River Company.

\section{REFERENCES}

1. S. Y. Lee, "Computational Fluid Dynamics Model for Saltstone Vault 4 Vapor Space”, WSRC-TR-2005-00288, Rev. 0, July 2005.

2. W. P. Jones and P. E. Launder, "The Prediction of Laminarization with a Two-Equation Model of Turbulence”, Int. J. of Heat and Mass Transfer, Vol. 15, pp. 301-314, 1972.

3. S. Y. Lee, R. A. Dimenna, R. A. Leishear, D. B. Stefanko, 2008, "Analysis of Turbulent Mixing Jets in a Large Scale Tank”, ASME Journal of Fluids Engineering, Volume 130, Number 1, pp. 011104.

4. Auer, L. H., Rosenberg, N. D., Birdsell, K. H., and Whitney, E. M., "The effects of barometric pumping on contaminant transport,” J. Contam. Hydrol., Vol. 24, pp. 145-166, 1996.
5. Nielsen, P. V., Restivo, A., and Whitelaw, J. H., "The Velocity Characteristics of Ventilated Rooms", J. of Fluids Engineering, Vol. 100, pp. 291-298, 1978.

6. Bird, R. B., Stewart W. E., and Lightfoot, E. N., Transport Phenomena, John Wiley \& Sons, New York, 1960.

7. FLUENT6, Fluent, Inc., 2005.

8. J. P. Holman, Introduction to Heat Transfer, Hemisphere Publishing Co., New York, 1969. 